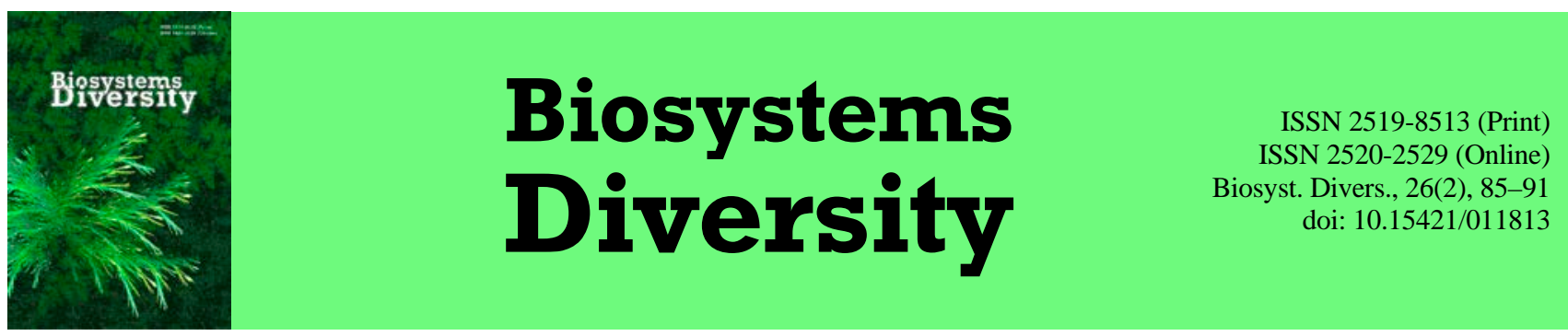

\title{
Ecomorphic structure of the soil macrofauna communities of technosols of the Nikopol Manganese Ore Basin
}

\author{
K. P. Maslikova \\ Dnipro State Agrarian and Economic University, Dnipro, Ukraine
}

Article info

Received 14.03.2018

Received in revised form 08.04.2018

Accepted 11.04.2018

Dnipro State Agrarian and Economic University, Sergey Yefremov st., 25, Dnipro, 49600, Ukraine. Tel.: +38-056-713-51-96 E-mail: mkaterina@ukr.net
Maslikova, K. P. (2018). Ecomorphic structure of the soil macrofauna communities of technosols.of the Nikopol Manganese Ore Basin. Biosystems Diversity, 26(2), 85-91. doi:10.15421/011813

This study established features of the animal population of artificial soil-like bodies - technosols in terms of ecomorphic analysis. The survey was conducted at the research station of the Dnipro State Agricultural University in the city Pokrov in 2012-2014. The experimental polygons were laid within four technosol types: pedozems, sod loess-like lithogenic soils on loam, grey-green clay and red-brown clay. The polygon consisted of 15 transects and each transect was composed of seven test sites. The distance between rows in the polygon was $3 \mathrm{~m}$. Each test site was a square with size $3 \times 3 \mathrm{~m}$. The manual sorting of the soilzoological samples was conducted within each site for areas $0.25 \times 0.25 \mathrm{~m}$ to the depth where animals were found. Samples were taken in late April or early May. In general, for each period of counting for each polygon 105 soil-zoological samples were taken 123 species of invertebrates were found in the soil macrofauna community of the technosols. These communities are a steppe monoceonosis with a tendency to transformations into pseudoomonoceonosis on account of increased share of pratants. The soil macrofauna of sod lithogenic soils on grey-green clay and loam on loes-like clays is most adapted to xerophilous condition. Animal communities in pedozems and sod-lithogenic soils or on red-brown clay have a more mesophilic character. The trophoceonomorphic structure of the soil macrofauna community indicates a significant potential of the fertility of artificial soil. The aeromorphs' structure reveals a significant ability of technosols to create cracks and pores, which can lead to hyperaeration. The dominant part of the of soil macrofauna community was hypercarbonatophils. Against the background of the steppe character, the soil macrofauna community had a topomorphic structure that is unusual for natural steppe black soil biogeocenoses on loess-like loam. The trophomorph structure was greatly dominated by phytophages, which indicates the prevalence of processes of mineralization of plant residues under the humification process. The phoromorphic spectrum of soil animal communities was dominated by ecological groups which move without the active construction of tunnels.

Keywords: ecomorphs; soil macrofauna; technosols; indication; reclamation

\section{Екоморфічна структура угруповань грунтової мезофауни техноземів Нікопольського марганцеворудного басейну}

\author{
К. П. Маслікова \\ Дніпровський державний аграрно-економічний університет, Дніпро, Україна
}

Установлено особливості тваринного населення штучних грунтоподібних тіл - техноземів у термінах екоморфічного аналізу. Дослідження проведене в науково-дослідному стаціонарі Дніпровського державного аграрного університету в м. Покров у 2012-2014 рр. Полігони закладені у межах чотирьох типів техноземів: педоземи, дерново-літогенні грунти на лесоподібних суглинках, сіро-зелених глинах та червоно-бурих глинах. Полігон складається з 15 трансект, а кожна трансекта складена 37 пробних майданчиків. Відстань між рядами в полігоні становить 3 м. Кожний майданчик являє собою квадрат розміром $3 \times 3$ м. У межах кожного майданчика проведене ручне розбирання грунтово-зоологічних проб розміром $0,25 \times 0,25$ м на глибину трапляння тварин. Проби відбирали в кінці квітня або на початку травня. Загалом, за кожний період обліків на кожному полігоні відібрано 105 грунтово-зоологічних проб. В угрупованнях грунтової мезофауни техноземів установлено 123 види безхребетних тварин. Ці угруповання - степовий моноценоз зі схильністю до трансформації у псевдомоноценоз за рахунок збільшення ролі пратантів. Найбільш адаптовані до ксерофільних умов існування - угруповання грунтової мезофауни дерново-літогенних грунтів на сіро-зелених глинах і на лесоподібних суглинках. У педоземах і дерново-літогенних грунтах на червоно-бурих глинах угруповання мають більш мезофільний характер. Трофоценоморфічна структура угруповання грунтової мезофауни вказує на значний потенціал родючості штучно створених грунтів. Структура аероморф підкреслює значну здатність техноземів до утворення тріщин і пор та, відповідно, до гіпераерації. Домінантна складова угруповання грунтової мезофауни - гіперкарбонатофіли. На фоні загального степового характеру угруповання грунтової мезофауни мають топоморфічну структуру, не характерну для природних степових біогеоценозів чорноземів на лесоподібних суглинках. У структурі трофоморф значно домінують фітофаги, що індикує переважання процесів мінералізації рослинних залишків над процесом гуміфікації. У спектрі фороморф домінують тварини, які пересуваються без активного прокладання ходів.

Ключові слова: екоморфи; грунтова мезофауна; техноземи; індикація; рекультивація 



\section{Вступ}

Грунтова мезофауна - екологічний комплекс, який складається 3 великих за розміром безхребетних. Важливість вивчення населення грунтових тварин зумовлена їх величезною роллю в житті грунту, де вони не тільки мешкають, а й активно формують структуру грунтових горизонтів (Brygadyrenko, 2015; Zhukov et al., 2017). Представники грунтової мезофауни беруть участь у багатьох грунтотвірних процесах і екосистемних сервісах, $є$ важливими екосистемними інженерами (Jones et al., 1994, 1997). До найактивніших перетворювачів середовища зазвичай відносять найбільших представників грунтової фауни, які радикально перетворюють фізичний стан грунтового середовища своєю локомоторною, будівельною чи трофічною активністю (Kunah, 2016). Головні «екосистемні інженери» (Jones et al., 1994) грунту - дощові черви (Decaëns \& Rossi, 2001). Основний вплив на структуру грунту вони чинять рийною активністю та формуванням викидів (копролітів). Рийна активність червів сприяє такому екосистемному сервісу як формування макро- та мікроагрегатів (Barois et al., 1993; Jiménez et al., 2014). Копрогенні грунти характеризуються підвищеним вмістом гумусу та рослинних. Грунтова мезофауна основна за біомасою група наземних тварин (Lavelle et al., 1997). Вона різноманітна у видовому відношенні, створює осіле населення, тісно контактує із грунтом (Gilarov, 1965). Безхребетні мешканці грунтового та підстилкового ярусів через специфіку їх місця існування становлять групу тварин, які зазнають значних прямих і опосередкованих антропогенних впливів (Rossi, 2003; Faly et al., 2017). Грунтові безхребетні характеризується значною стабільністю та стійкістю навіть у сильно змінених людиною екосистемах, де часто залишаються останньою групою, за якою можна оцінити ступінь впливу на біоту (Krivolutsky, 1994).

Будь-яка зміна середовища існування безпосередньо відбивається на складі грунту та його біоти, що дозволяє використовувати як весь комплекс грунтової мезофауни, так і окремі таксономічні групи як надійні індикатори стану природних угруповань (Whalen, 2004; Zhukov \& Shatalin, 2016). Грунтові безхребетні живуть здебільшого у верхніх акумулятивних горизонтах грунту (Decaëns et al., 2006; Brygadyrenko, 2016). Видовий склад їх угруповань найбільшою мірою змінюється як у процесі природного сукцесійного розвитку біогеоценозу, так і за антропогенного впливу, і тому на різних стадіях природних і антропогенних сукцесій формуються унікальні комплекси грунтових безхребетних (Drake, 1990; Zhukov et al., 2016).

Екоморфи відбивають ставлення живих організмів до екологічних факторів. За Williams (1947), до космічних факторів належать світло та тепло, а до наземних - вода та їжа. Відношення до космічних факторів відбивають клімаморфи, термоморфи, геліоморфи рослин і тварин (Akimov, 1954; Zhukov \& Zadorozhnaya, 2016), а також трофоценоморфи та топоморфи тварин (Zhukov et al., 2016). Ставлення до наземних факторів характеризують трофоморфи та гігроморфи (Andrusevich et al., 2014; Kharytonov et al., 2018). Останні характеризують преференції організмів до градацій режиму зволоження грунту (Zhukov et al., 2017), а трофоморфи (трофоценоморфи тварин) - до градацій трофності едафотопу (Kunah et al., 2014). Гігроморфи та трофоценоморфи виділяються за допомогою вивчення горизонтальної диференціації живого покриву. 3 боку вертикальної диференціації тваринного населення грунтів можуть бути виділені топоморфи - підстилкові, грунтові та норні форми. Топоморфи вказують на ярус, якому віддає перевагу екологічна група, а також на зосередження функціональної активності тварин. Трофоморфи диференціюють тваринне населення за ознакою способу живлення та особливостями трофічного впливу на середовище існування (Svyrydchenko \& Brygadyrenko, 2014). Спектри гігроморф, трофоценоморф, топоморф і трофоморф дозволяють одержати уявлення про екологічне різноманіття угруповання. Ці ознаки дозволяють установити стосунки розбіжності або подібності між видами тварин, що становлять угруповання. Сукупність таких характеристик угруповання як спектри екоморф, індекси екологічного різноманіття та організації, ін- декси видового різноманіття та функціональні ознаки угруповань становлять основу екоморфічної матриці (Zhukov et al., 2017).

Якісні та кількісні показники структури грунтової мезофауни відображають як особливості стану грунтової динаміки, так і фауністичні риси, властиві певним місцям мешкання (Gongalsky et al., 2008). Тому за різноманіттям і чисельністю грунтових безхребетних можна $з$ достатньою точністю оцінювати ступінь трансформації середовища існування (Gongalsky et al., 2009). Посилення антропогенного та техногенного тиску викликає необхідність розроблення методів, що дають змогу своєчасно виявити деградацію, встановити довготривалі тенденції та буферну здатність природних екосистем до негативних факторів, з одного боку, а з іншого дозволяють виявити позитивний розвиток техногенно трансформованих земель (Zverkovskyi et al., 2017), напрямок їх розвитку та створити прогноз щодо швидкості відновлення їх продуктивності (Krivolutsky, 1994). Зоологічна діагностика грунтів - це встановлення відповідності та інформаційного зв'язку між типологічними одиницями грунтового покриву та емерджентними властивостями тваринного населення грунтів (Zhukov, 2009). Грунтово-зоологічні дослідження дають змогу використовувати грунтових тварин для характеристики умов їх існування, їх зміни від техногенного або господарського впливу - перспективного та актуального питання використання рекультивованих грунтів для сільськогосподарських угідь (Mordkovich, 1977). Грунтові тварини беруть безпосередню участь у процесах грунтоутворення, в чому і полягає їх діагностичне значення. Перевага зоологічного методу діагностики грунтів полягає у швидкості реакції організмів на зміни умов існування (Mordkovich, 2013).

Мета цього дослідження - встановити особливості тваринного населення штучних грунтоподібних тіл - техноземів у термінах екоморфічного аналізу.

\section{Матеріал і методи досліджень}

Дослідження проведене в науково-дослідному стаціонарі Дніпровського державного аграрно-економічного університету в м. Покров у 2012-2014 pp. Полігони закладені у межах чотирьох типів техноземів: педоземи, дерново-літогенні грунти на лесоподібних суглинках, сіро-зелених глинах і червоно-бурих глинах. Полігон складається 315 трансект, а кожна трансекта складена 37 пробних майданчиків. Відстань між рядами полігону становить 3 м. Кожний майданчик являє собою квадрат розміром $3 \times 3$ м. У межах кожного майданчика проведене ручне розбирання грунтово-зоологічних проб розміром $0,25 \times 0,25$ м на глибину зустрічі тварин. Проби відбирали у кінці квітня або на початку травня. Загалом, за кожний період обліків на кожному полігоні відібрано 105 грунтово-зоологічних проб. Таким чином, за весь період досліджень відібрано 1260 проб, у яких перебувало 14338 екз. безхребетних тварин. Таблиці видів і описання грунтових профілів техноземів наведені Zhukov et al. (2017). Таксономія та номенклатура грунтових безхребетних наведена за базою даних Fauna Europea (de Jong, 2013; Fauna Europaea version 2.6. Web Service available online at www.faunaeur.org). Характеристика екоморф грунтових тварин наведена за Zhukov (2009).

\section{Результати та їх обговорення}

Ценоморфічна структура мезофауни техноземів. У ценоморфічній структурі мезофауни техноземів представлені палюданти, пратанти, сильванти та степанти (табл. 1). У ценоморфічному спектрі угруповання мезофауни дерново-літогенних грунтів на лесоподібних суглинках домінантне положення займають степанти (74,2-94,8\%). Дещо меншу роль в угрупованні відіграють пратанти (4,9-22,8\%) та епізодично зустрічаються сильванти $(0,4$ $3,0 \%$ ). Одержані результати свідчать про те, що угруповання грунтової мезофауни дерново-літогенних грунтів на лесоподібних суглинках має ярко виражений степовий характер. Таке угруповання можна оцінити як степовий моноценоз зі схильністю в окремі роки до трансформації у псевдомоноценоз за рахунок збільшення 
ролі пратантів. У спектрі ценоморф угруповання грунтової мезофауни дерново-літогенних грунтів на червоно-бурих глинах безумовно домінують степанти. Їх частка в угрупованні коливається в незначних межах (93,5-98,3\%). Пратанти та сильванти зустрічаються епізодично. Таким чином, угруповання безхребетних дерново-літогенних грунтів на червоно-бурих глинах має характер степового моноценозу.

\section{Таблиця 1}

Екоморфічна структура угруповань грунтової мезофауни техноземів (\% від загальної чисельності угруповання)

\begin{tabular}{lccccc}
\hline \multicolumn{1}{c}{ Тип техноземів } & Piк & Pal & Pr & Sil & St \\
\hline \multirow{2}{*}{ Дерново-літогенні грунти } & 2012 & - & 2,54 & 0,56 & 96,90 \\
на червоно-бурих глинах & 2013 & - & 0,68 & 1,03 & 98,29 \\
& 2014 & - & 1,26 & 5,26 & 93,47 \\
\hline \multirow{2}{*}{ Дерново-літогенні грунти } & 2012 & - & 16,33 & 1,57 & 82,10 \\
\multirow{2}{*}{ на лесоподібних суглинках } & 2013 & - & 4,87 & 0,35 & 94,78 \\
& 2014 & - & 22,84 & 2,99 & 74,17 \\
\hline \multirow{2}{*}{ Педозем } & 2012 & - & 1,05 & 0,52 & 98,43 \\
& 2013 & - & 1,42 & 0,47 & 98,10 \\
\multirow{2}{*}{ Дерново-літогенні грунти на } & 2014 & - & 0,55 & 1,65 & 97,79 \\
сіро-зелених глинах & 2012 & 0,12 & 2,45 & 0,31 & 97,12 \\
& 2013 & - & 0,22 & 1,10 & 98,69 \\
& 2014 & 0,46 & 0,61 & 5,17 & 93,77 \\
\hline
\end{tabular}

Примітка: Pal - палюданти, Pr - пратанти, Sil - сильванти, St - степанти.

У структурі ценоморф грунтової мезофауни дерново-літогенних грунтів на сіро-зелених глинах домінують степанти (93,898,7\%). Пратанти та сильванти зустрічаються епізодично. Слід також відзначити епізодичні трапляння палюдантів. Палюданти надають специфічності угрупованню грунтової мезофауни на сіро-зелених глинах. Очевидно, висока вологоємність такого субстрату створює локальні умови для існування болотних видів у загальному степовому оточенні.

У структурі ценоморф грунтової мезофауни педоземів домінують степанти. Частка їх в угрупованні коливається в межах 97,8-98,1\%. Пратанти та сильванти зустрічаються епізодично.

Таким чином, угруповання грунтової мезофауни техноземів переважно представлені степантами, які складають абсолютну більшість комплексів. Тільки у 2012 та 2014 рр. на дерново-літогенних грунтах на лесоподібних суглинках спостерігали зменшення частки цієї ценоморфи за рахунок пратантів. Угруповання грунтової мезофауни педоземів, дерново-літогенних грунтів на сірозелених і червоно-бурих глинах можна ідентифікувати як степовий моноценоз, а угруповання дерново-літогенних грунтів на лесоподібних суглинках можна оцінити як степовий псевдомоноценоз із лучною компонентою. Сильванти зустрічаються епізодично. Джерело їх розселення - лісові насадження, які оточують експериментальний полігон із техноземами. Ця обставина підкреслює важливу роль ландшафтного різноманіття в межах рекультивованих земель. Але невелика частка сильвантів - це маркер недостатнього розвитку лісових насаджень.

Палюданти трапляються вкрай епізодично і тільки в техноземах, які сформувалися на сіро-зелених глинах, що підкреслюе специфічність і контрастність водного режиму цих утворень.

Індикація водного режиму техноземів та гігроморфічна структура мезофауни. У спектрі гігроморф угруповання мезофауни на дерново-літогенних грунтах на лесоподібних суглинках за період дослідження домінували ксерофільні види безхребетних (66,6-79,4\%) (табл. 2). Дещо меншу роль в угрупованні відігірають мезофіли (20,3-33,0\%). Гігрофіли та ультрагігрофіли зустрічаються спорадично. Таким чином, на фоні переважання ксерофілів, що досить природно для степових угруповань, потужно представлені мезофіли. Слід зауважити, що ксерофільні умови можна визначити як екстремальні для переважної більшості рослинних і тваринних організмів. Одержані результати свідчать про те, що лесоподібні суглинки характеризуються комплексом властивостей, які створюють умови для тренду загальноксерофільних умов у напрямку їх мезофілізації, що може позитивно позначитися на збільшенні екологічної ємності цього місцеперебування. У струк- турі гігроморф угруповання грунтової мезофауни дерново-літогенних грунтів на червоно-бурих глинах домінують мезофіли (59,6-71,2 \%) (табл. 2). Ксерофіли поступаються своїм значенням в угрупованні $(26,6-40,4 \%)$. Гігрофіли та ультрагігрофіли трапляються епізодично. У спектрі гігроморф грунтової мезофауни дерново-літогенних грунтів на сіро-зелених глинах домінують ксерофіли $(66,3-81,1 \%)$. Мезофіли значно поступаються ксерофілам, але складають значну компоненту угруповання (16,7-33,4\%). У спектрі гігроморф грунтової мезофауни педоземів ксерофіли та мезофіли мають приблизно рівне значення $(32,2-53,4 \%$ та 46,366,5\% відповідно).

\section{Таблиця 2}

Гігроморфічна структура угруповань грунтової мезофауни техноземів (\% від загальної чисельності угруповання)

\begin{tabular}{lccccc}
\hline \multicolumn{1}{c}{ Тип техноземів } & Piк & $\mathrm{Ks}$ & $\mathrm{Ms}$ & $\mathrm{Hg}$ & $\mathrm{UHg}$ \\
\hline \multirow{2}{*}{ Дерново-літогенні грунти } & 2012 & 26,63 & 71,21 & 2,04 & 0,12 \\
на червоно-бурих глинах & 2013 & 36,82 & 63,18 & - & - \\
& 2014 & 40,42 & 59,58 & - & - \\
\hline \multirow{2}{*}{ Дерново-літогенні грунти } & 2012 & 68,91 & 28,21 & 2,62 & 0,26 \\
\multirow{2}{*}{ на лесоподібних суглинках } & 2013 & 66,57 & 32,96 & 0,48 & - \\
& 2014 & 79,40 & 20,28 & 0,21 & 0,11 \\
\hline \multirow{2}{*}{ Педозем } & 2012 & 50,04 & 48,99 & 0,79 & 0,17 \\
& 2013 & 32,23 & 66,54 & 1,14 & 0,09 \\
\multirow{2}{*}{ Дерново-літогенні грунти } & 2014 & 53,40 & 46,32 & 0,28 & - \\
\multirow{2}{*}{ на сіро-зелених глинах } & 2012 & 81,12 & 16,68 & 2,08 & 0,12 \\
& 2013 & 74,00 & 25,79 & 0,22 & - \\
\hline
\end{tabular}

Примітка: Ks - ксерофіли, Ms - мезофіли, $\mathrm{Hg}$ - гігрофіли, UHg - ультрагігрофіли.

Найбільш адаптовані до ксерофільних умов існування угруповання грунтової мезофауни дерново-літогенних грунтів на сірозелених глинах або на лесоподібних суглинках (Zhukov et al., 2017). У педоземах і дерново-літогенних грунтах на червоно-бурих глинах угруповання мають більш мезофільний характер. В окремі роки відбуваються спалахи чисельності гігрофілів у таких типах техноземів, що сформовані на червоно-бурих, сіро-зелених глинах або на лесоподібних суглинках, але ніколи такі спалахи не встановлені для педоземів. Частка гігрофілів в угрупованні вкрай низька. Трапляння ультрагігрофілів спорадичні. Очевидно, що серед гігрофілів та ультрагігрофілів зустрічаються винятково евритопні представники.

Режим живлення техноземів та трофоценоморфічна структура мезофауни. У структурі трофоценоморф угруповання мезофауни дерново-літогенного грунту на лесоподібних суглинках за весь період дослідження домінують мегатрофоценоморфи (91,494,7\%) (табл. 3).

\section{Таблиця 3}

Трофоценоморфічна структура угруповань грунтової мезофауни техноземів (\% від загальної чисельності угруповання)

\begin{tabular}{lccrcc}
\hline \multicolumn{1}{c}{ Тип техноземів } & Piк & OlgTr & MsTr & MgTr & UMgTr \\
\hline \multirow{2}{*}{ Дерново-літогенні грунти } & 2012 & 3,03 & 3,84 & 92,38 & 0,74 \\
на червоно-бурих глинах & 2013 & 6,36 & 5,93 & 87,15 & 0,56 \\
& 2014 & 5,41 & 16,60 & 72,76 & 5,22 \\
\hline \multirow{2}{*}{ Дерново-літогенні грунти } & 2012 & 4,63 & 2,62 & 91,70 & 1,05 \\
\multirow{2}{*}{ на лесоподібних суглинках } & 2013 & 1,87 & 2,57 & 94,74 & 0,83 \\
& 2014 & 1,75 & 5,14 & 91,36 & 1,75 \\
\hline \multirow{2}{*}{ Педозем } & 2012 & 1,22 & 0,52 & 97,55 & 0,70 \\
& 2013 & 4,17 & 1,52 & 94,03 & 0,28 \\
\multirow{2}{*}{ Дерново-літогенні грунти } & 2014 & 1,47 & 4,87 & 90,90 & 2,76 \\
\hline \multirow{2}{*}{ на сіро-зелених глинах } & 2012 & 3,07 & 0,86 & 94,79 & 1,29 \\
& 2014 & 3,58 & 3,51 & 92,55 & 0,37 \\
\hline
\end{tabular}

Примітка: $\mathrm{Olg} \mathrm{Tr}$ - оліготрофоценоморфи, MsTr - мезотрофоценоморфи, $\mathrm{MgTr}$ - мегатрофоценоморфи, UMgTr - ультрамегатрофоценоморфи.

Значно менше в угрупованні представлені мезотрофоценоморфи (2,6-5,1\%) та ультрамегатрофоценоморфи (0,8-1,8\%). Значно варіює частка в угрупованні оліготрофоценоморф $(1,8-4,6 \%)$. 
Таким чином, угруповання грунтової мезофауни дерново-літогенного грунту на лесоподібних суглинках має загальний мегатрофний вигляд, що вказує на значний потенціал родючості цих техноземів. Основну частину трофоценоморф угруповання грунтової мезофауни дерново-літогенних грунтів на червоно-бурих глинах складали мегатрофоценоморфи (72,8-92,4\%). Частка мезотрофоценоморф варіювала у широких межах (3,8-16,6\%). Порівняно стабільною, але незначною, була частка оліготрофоценоморф $(3,0-5,4 \%)$. Ультрамегатрофоценоморфи перебували на рівні $0,6-$ $0,7 \%$, але у 2014 р. спостерігався значний спалах чисельності цієї трофоценоморфи до рівня 5,2\%. У структурі трофоценоморф грунтової мезофауни дерново-літогенних грунтів на сіро-зелених глинах превалюють мегатрофоценоморфи (91,7-94,8\%). Частка мезотрофоценоморф становить $0,9-9,5 \%$. У структурі трофоценоморф грунтової мезофауни педоземів також домінують мегатрофоценоморфи. Частка їх участі коливається у порівняно невеликих межах (90,9-97,6\%). Таким чином, мегатрофоценоморфи в угрупованнях усіх типів техноземів є домінантами, що вказує на значний потенціал родючості штучно створенних грунтів. Найбільша роль в угрупованні цієї трофоценоморфи характерна для педоземів, що природно, оскільки цей тип техноземів створений із застосуванням гумусованного чорноземовидного субстрату. Найстабільніша у часі частка мегатрофоценоморф угруповань мезофауни на лесоподібних суглинках. У свою чергу, для угруповань на сіро-зелених або червоно-бурих глинах цей показник вкрай нестабільний. У періоди значних флуктуацій мегатрофоценоморфи у цих техноземах заміщуються мезотрофоценоморфами. Ультрамегатрофоценоморфи та оліготрофоценоморфи - це факультативні компоненти угруповань, оскільки чисельність незначна та зазнає значних флуктуацій.

Ірунтове повітря техноземів та аероморфічна структура мезофауни. Аерація - показник, який відображає роль забезпечення грунту повітрям і роль цього фактора у перебігу хімічних процесів (окиснення чи відновлення), у формуванні складу та розвитку грунтової мікрофлори та може лімітувати поширення багатьох видів рослин. Аероморфи грунтових тварин - екологічні групи, які об'єднують види, що віддають перевагу подібним умовам аерації грунту. Аналогічно класифікації рослин, виділяють аерофіли, субаерофіли, геміаерофоби та субаерофоби (Zhukov et al., 2016). В угрупованнях грунтової мезофауни техноземів представлені аерофіли, субаерофіли та геміаерофоби (табл. 4).

\section{Таблиця 4}

Аероморфічна структура угруповань грунтової мезофауни техноземів (\% від загальної чисельності угруповання)

\begin{tabular}{lcccc}
\hline \multicolumn{1}{c}{ Тип техноземів } & Piк & APhil & SAPhil & HAPhob \\
\hline \multirow{2}{*}{ Дерново-літогенні грунти } & 2012 & 76,84 & 13,75 & 9,41 \\
на червоно-бурих глинах & 2013 & 81,68 & 17,29 & 1,03 \\
& 2014 & 61,26 & 32,84 & 5,89 \\
\hline \multirow{2}{*}{ Дерново-літогенні грунти } & 2012 & 80,26 & 18,86 & 0,87 \\
на лесоподібних суглинках & 2013 & 85,52 & 12,30 & 2,17 \\
& 2014 & 79,08 & 17,50 & 3,42 \\
\multirow{2}{*}{ Педозем } & 2012 & 83,90 & 8,75 & 7,35 \\
& 2013 & 78,20 & 11,56 & 10,24 \\
\multirow{2}{*}{ Дерново-літогенні грунти } & 2014 & 65,81 & 21,60 & 12,59 \\
на сіро-зелених глинах & 2012 & 86,57 & 10,48 & 2,94 \\
& 2013 & 85,98 & 8,47 & 5,55 \\
\hline
\end{tabular}

Примітка: APhil - аерофіли, SAPhil- субаерофіли, HAPhob - субаерофоби.

Основу угруповання складають аерофіли. Стабільно висока їх частка характерна для угруповань дерново-літогенних грунтів на лесоподібних суглинках. Також високий рівень участі аерофілів в угрупованнях техноземів на сіро-зелених глинах, але у деякі роки їх частка може знижуватися. В дерново-літогенних грунтах на червоно-бурих глинах частка аерофілів може знижуватися суттєво. В останніх двох типах техноземів частка аерофілів під час зниження їх чисельності заміщується субаерофілами. В інших грунтах показник субаерофілів досить константний. Субаерофоби найбільшою мірою характерні для педоземів, де їх частка найбільша серед досліджених техноземів. Таким чином, угруповання грунтових тварин техноземів переважно представлені формами, чутливими до рівня аерації грунтового простору. Умови, сприятливі для аерофілів та субаерофілів, утворюються за значного рівня шпаруватості аерації та міжагрегатної шпаруватості. Структура аероморф підкреслює значну здатність техноземів до утворення тріщин і пор. Гіпераерація не формує сприятливі екологічні умови у грунті, оскільки внаслідок цього створюються окисні умови та прискорюється випаровування вологи із грунту.

Структура карбонатоморф мезофауни техноземів. Карбонатоморфи - екологічна група, яка об'єднує грунтових тварин, що віддають перевагу подібним умовам карбонатності грунту. Аналогічно класифікації рослин, виділяють карбонатофоби, акарбонатофіли, гемікарбонатофіли, карбонатофіли та гіперкарбонатофіли. Усі вказані екологічні групи представлені в техноземах (табл. 5).

\section{Таблиця 5}

Структура карбонатоморф угруповань грунтової мезофауни техноземів (\% від загальної чисельності угруповання)

\begin{tabular}{cccrccc}
\hline Тип техноземів & Piк & $\begin{array}{c}\text { Car- } \\
\text { Phob }\end{array}$ & $\begin{array}{c}\text { Acar- } \\
\text { Phil }\end{array}$ & $\begin{array}{c}\text { Hemi- } \\
\text { CarPhil }\end{array}$ & CarPhil & $\begin{array}{c}\text { Hiper- } \\
\text { CarPhil }\end{array}$ \\
\hline Дерново-літогенні & 2012 & 0,00 & 7,43 & 13,62 & 51,52 & 27,43 \\
грунти на червоно- & 2013 & 0,00 & 5,65 & 10,59 & 45,06 & 38,70 \\
бурих глинах & 2014 & 0,00 & 24,07 & 15,49 & 25,93 & 34,51 \\
\hline Дерново-літогенні & 2012 & 0,09 & 10,22 & 24,02 & 28,38 & 37,29 \\
грунти на & 2013 & 0,00 & 3,74 & 18,43 & 25,91 & 51,91 \\
лесоподібних & 2014 & 0,10 & 9,77 & 15,33 & 26,34 & 48,46 \\
суглинках & 2012 & 0,00 & 4,72 & 7,00 & 35,00 & 53,28 \\
\hline & 2013 & 0,00 & 3,41 & 1,71 & 48,44 & 46,45 \\
Педозем & 2014 & 0,00 & 10,02 & 9,28 & 13,88 & 66,82 \\
\hline Дерново-літогенні & 2012 & 0,00 & 8,15 & 7,11 & 7,17 & 77,56 \\
грунти на сіро- & 2013 & 0,00 & 3,29 & 6,06 & 14,68 & 75,97 \\
зелених глинах & 2014 & 0,26 & 14,82 & 7,60 & 7,22 & 70,10 \\
\hline
\end{tabular}

Примітка: CarPhob - карбонатофоби, ACarPhil - акарбонатофіли, HemiCarPhil - гемікарбонатофіли, CarPhil - карбонатофіли, HiperCarPhil - гіперкарбонатофіли.

Домінантна складова угруповання грунтової мезофауни - гіперкарбонатофіли. Гіперкарбонатофіли (облігатні карбонатофіли) існують винятково на відкладах карбонатів (крейди, вапняків) (CaO, MgO > 10\%) (Didukh, 2011). Найбільший рівень гіперкарбонатофілів характерний для педоземів і дерново-літогенних грунтів на сіро-зелених глинах.

Наступна за значимістю група карбонатофілів. Карбонатофіли віддають перевагу карбонатним грунтам (CaO, $\mathrm{MgO}=5-10 \%)$ (Didukh, 2011). Найхарактерніші для угруповань дерново-літогенних грунтів на червоно-бурих глинах, їх дещо менше на техноземах на лесоподібних суглинках і педоземах. Частка на техноземах на сіро-зелених глинах незначна.

Гемікарбонатофіли поширені на чорноземах, достатньо збагачених карбонатами $(\mathrm{CaO}, \mathrm{MgO}=1,5-5,0 \%)$, що не вимиваються та можуть траплятись у вигляді невеликих включень, конкрецій (Didukh, 2011). Найхарактерніші для дерново-літогенних грунтів на лесоподібних суглинках і червоно-бурих глинах. В останньому випадку спостерігається висока варіабельність цього показника по роках.

Акарбонатофіли існують у нейтральних екотопах і витримують незначний вміст карбонатів у грунті (CaO, $\mathrm{MgO}=0,5-1,5 \%)$, які завдяки промивному режиму не піднімаються у верхні шари. 3 одного боку, це сірі лісові грунти, що хоча й формуються на лесовій основі, але характеризуються процесами опідзолення. 3 іншого - це солонці, солончаки, де карбонатна основа заміщується сульфатами та хлоридами (Didukh, 2011). Найхарактерніші для дерново-літогенних грунтів на червоно-бурих глинах.

Карбонатофоби нечисленні, трапляються спорадично. Карбонатоморфи безпосередньо віддзеркалюють ставлення тварин до вмісту у грунті кальцію, який найбільше міститься у формі карбонатів. Багато тварин - кальцефіли, що відповідає карбонатофілам або гіперкарбонатофілам. Кальцій - важливий агент чорноземного типу грунтоутворення. У грунтовому поглинальному комплексі з кальцієм можуть конкурувати натрій за умов засолення грунтів. Замі- 
щення кальцію натрієм спричиняє втрати водостійкості грунтової структури. Крім того, самі грунтові тварини можуть бути фактором формування агрегатної структури. Структура може мати зоогенне походження. Це можуть бути як копроліти, так і безпосередньо екзувій або черепашки тварин-кальцефілів.

Структура карбонатоморф вказує на те, що оптимальні умови для формування агрономічно цінної структури грунту характерні для дерново-літогенних грунтів на лесоподібних суглинках. За задумом створення педоземів найсприятливіші умови повинні бути саме в них, але зооіндикація вказує на певні недоліки такої конструкції. Горизонтальна штучна стратифікація педоземів - головний недолік такої конструкції. Гомогенний характер техноземів має значно більший позитивний динамічний потенціал для грунтогенезу в контексті формування повнопрофільних високопродуктивних грунтів, які можуть використовуватися в сільському господарстві.

Вертикальний розподіл функиіональної активності в екосистемах техноземів і топоморфічна структура мезофауни. У спектрі топоморф угруповання грунтової мезофауни грунтових тварин усіх типів техноземів домінують епігейні форми (табл. 6). Частка епігейних форм дерново-літогенних грунтів на лесоподібних суглинках найменша серед усіх техноземів (68,1-91,8\% угруповання). Найбільша частка епігейних форм характерна для педоземів (76,7$89,9 \%$ ) та для техноземів на сіро-зелених глинах (68,1-91,6 \%).

\section{Таблиця 6}

Топоморфічна структура угруповань грунтової мезофауни техноземів (\% загальної чисельності угруповання)

\begin{tabular}{lcccc}
\hline \multicolumn{1}{c}{ Тип техноземів } & Рік & Anec & End & Ep \\
\hline \multirow{2}{*}{ Дерново-літогенні грунти } & 2012 & 0,19 & 13,87 & 85,94 \\
на червоно-бурих глинах & 2013 & 0,51 & 15,41 & 84,08 \\
& 2014 & 0,42 & 30,95 & 68,63 \\
\hline \multirow{2}{*}{ Дерново-літогенні грунти } & 2012 & 0,79 & 33,80 & 65,41 \\
на лесоподібних суглинках & 2013 & 0,52 & 18,09 & 81,39 \\
& 2014 & 0,21 & 37,78 & 62,01 \\
\multirow{2}{*}{ Педозем } & 2012 & 0,35 & 9,71 & 89,94 \\
& 2013 & 0,38 & 12,80 & 86,82 \\
\multirow{2}{*}{ Дерново-літогенні грунти } & 2014 & 0,46 & 22,89 & 76,65 \\
\multirow{2}{*}{ на сіро-зелених глинах } & 2012 & 0,61 & 11,53 & 87,86 \\
& 2013 & 0,44 & 7,96 & 91,60 \\
\end{tabular}

Примітки: Anес- норники, End - ендогейні, Ер - епігейні.

Характерна особливість техноземів на лесоподібних суглинках - найбільша серед усіх угруповань частка ендогейних форм. Топоморфи загалом вказують на розподіл активності грунтотвірного процесу та роль у ньому тварин. Тварини мають велике значення у трансформації органічної речовини. Можливість поширення біотичної складової грунтотвірного процесу вглиб гірської породи - важлива умова швидкості трансформації гірських порід у родючий грунт. Ендогейна складова комплексу грунтових безхребетних досить консервативна, вона може розглядатися як маркер стійкості угруповання. Оптимальна екологічна структура угруповання грунтової мезофауни характерна для дерново-літогенних грунтів на лесоподібних суглинках. Таким чином, на фоні загального степового характеру, угруповання грунтової мезофауни мають топоморфічну структуру, не характерну для природних степових біогеоценозів чорноземів на лесоподібних суглинках. Більшою мірою переважання епігейних форм властиве степовим угрупованням на пісках борових терас степових річок (Zhukov, 2015).

Фороморфічна структура мезофауни техноземів. У спектрі фороморф угруповання грунтової мезофауни грунтових тварин дерново-літогенних грунтів на лесоподібних суглинках домінують види, які належать до фороморфи $\mathrm{A}_{3}$ - тварини, які пересуваються без активного прокладання ходів і розміри тіла яких більші за порожнини у підстилці (табл. 7).

Підлегле положення у структурі фороморф займають тварини, які належать до фороморфи $\mathrm{B}_{4}-$ ті, що активно прокладають свердловини та ходи, змінюючи товщину тіла. Частка інших фороморф порівняно незначна. Ценоморфічний аналіз свідчить про те, що тваринне населення дерново-літогенних грунтів на лесопо- дібних суглинках можна охарактеризувати як степовий моноценоз. За преференцією умов вологості едафотопу - як мезоксерофільне, тобто таке, що тяжіє до сухуватих біотопів.

\section{Таблиця 7}

Фороморфічна структура угруповань грунтової мезофауни техноземів (\% загальної чисельності угруповання)

\begin{tabular}{lcrcccccc}
\hline \multirow{2}{*}{ Тип техноземів } & \multirow{2}{*}{ Рік } & \multicolumn{4}{c}{$\mathrm{A}$} & \multicolumn{5}{c}{$\mathrm{B}$} \\
\cline { 3 - 9 } & & 1 & 2 & 3 & 4 & \multicolumn{1}{c}{6} & \multicolumn{1}{c}{7} \\
\hline Дерново-літогенні & 2012 & 3,34 & 0,37 & 82,91 & 0,50 & - & 11,21 & 1,67 \\
грунти на червоно- & 2013 & 6,34 & 0,51 & 78,08 & 0,68 & - & 13,87 & 0,51 \\
бурих глинах & 2014 & 11,37 & 1,47 & 56,84 & 4,84 & 0,42 & 18,95 & 6,11 \\
\hline Дерново-літогенні & 2012 & 5,41 & 1,05 & 60,26 & 26,90 & 0,09 & 4,54 & 1,75 \\
грунти на лесопо- & 2013 & 1,00 & 0,91 & 79,96 & 13,48 & 0,35 & 2,00 & 2,30 \\
дібних суглинках & 2014 & 2,24 & 0,43 & 59,34 & 31,70 & 0,21 & 4,48 & 1,60 \\
\hline & 2012 & 0,96 & 0,79 & 89,15 & 0,79 & 0,09 & 7,61 & 0,61 \\
Педозем & 2013 & 0,38 & 0,76 & 86,26 & 0,47 & - & 11,94 & 0,19 \\
& 2014 & 3,13 & 0,46 & 73,35 & 2,21 & 0,74 & 17,56 & 2,57 \\
\hline Дерново-літогенні & 2012 & 3,56 & 0,86 & 84,37 & 0,55 & - & 9,93 & 0,74 \\
грунти на сіро-зеле-- & 2013 & 2,78 & 0,51 & 88,82 & 0,95 & - & 6,65 & 0,29 \\
них глинах & 2014 & 5,78 & 0,76 & 62,16 & 6,08 & 0,61 & 20,52 & 4,10 \\
\hline
\end{tabular}

Примітки: А - переміщення за допомогою існуючої шпаруватості грунту; В - активне прокладання ходів; 1 - розміри тіла менші шпар у грунті; 2 - розміри тіла співрозмірні $з$ тріщинами; 3 - розміри тіла більші порожнин у підстилці або співрозмірні з великими щілинами або тріщинами у грунті; 4 - переміщення зі зміною товщини тіла; 5 - переміщення без змін товщини тіла; 6 - риття нір за допомогою кінцівок; 7 - С-подібна форма тіла.

Угруповання безхребетних на дерново-літогенних грунтах на лесоподібних суглинках в аспекті трофоценоморфічної структури можна охарактеризувати як таке, що тяжіє до багатих, родючих грунтів. Із погляду топоморфічної структури превалюють епігейні види, у підлеглому положенні перебувають ендогейні, частка норників в угрупованні незначна. Це вказує на відносно високий рівень активності грунтової мезофауни у підстилкових горизонтах грунту порівняно 3 мінеральними. 3 погляду трофоморфічної структури, в угрупованні домінують фітофаги, що свідчить про переважання процесів мінералізації над процесами гуміфікації.

У структурі фороморф угруповання грунтової мезофауни дерново-літогенних грунтів на червоно-бурих глинах також домінують тварини, які належать до фороморфи $\mathrm{A}_{3}$ - тварини, які пересуваються без активного прокладання ходів і розміри тіла яких більші за порожнини у підстилці. Підлегле положення займають форми, віднесені до фороморф $\mathrm{B}_{6}$ (тварини, які активно прокладають свердловини у грунті та риють нори за допомогою кінцівок) та $\mathrm{A}_{1}$ (тварини, які пересуваються без активного прокладання ходів і розміри тіла яких більші за порожнини у підстилці). У спектpi фороморф грунтової мезофауни дерново-літогенних грунтів на сіро-зелених глинах домінують організми, віднесені до фороморфи $\mathrm{A}_{3}$. У підлеглому положенні - фороморфа $\mathrm{B}_{6}$. У спектрі фороморф грунтової мезофауни педоземів домінує фороморфа $\mathrm{A}_{3}$ протягом усього періоду дослідження.

Трофоморфічна структура мезофауни техноземів. У структурі трофоморф угруповання грунтової мезофауни грунтових тварин дерново-літогенних грунтів на лесоподібних суглинках весь період дослідження домінують фітофаги - 55,5-66,9\% (табл. 8). Особливість дерново-літогенних грунтів полягає у порівняно значній частці сапрофагів в угрупованні, що становить 29,7-39,7\%. Зоофаги займають підлегле положення - 2,6-4,9\%.

У структурі трофоморф грунтової мезофауни дерново-літогенних грунтів на червоно-бурих глинах ключову роль відігравали сапрофаги $(22,3-51,0 \%)$ та фітофаги $(45,3-63,2 \%)$. Частка зоофагів становила 3,8-14,5\%. У структурі трофоморф грунтової мезофауни дерново-літогенних грунтів на сіро-зелених глинах протягом усього періоду дослідження превалюють фітофаги, частка їх коливається в межах 82,0-89,0\%. Відсоток сапрофагів становив 3,3$12,6 \%$. Частка зоофагів поступово збільшується з року в рік - 3,7\% (2012 p.), 5,3\% (2013 p.), 9,6\% (2014 р.). У структурі трофоморф грунтової мезофауни педоземів домінували фітофаги (49,2-83,4\%). У підлеглому положенні перебували сапрофаги $(13,4-46,5 \%)$ та зоофаги $(2,8-4,4 \%)$. 


\section{Таблиця 8}

Трофоморфічна структура

угруповань грунтової мезофауни техноземів

\begin{tabular}{lccrr}
\hline \multicolumn{1}{c}{ Тип техноземів } & Рік & FF & \multicolumn{1}{c}{ SF } & ZF \\
\hline \multirow{2}{*}{ Дерново-літогенні грунти } & 2012 & 45,26 & 50,96 & 3,78 \\
на червоно-бурих глинах & 2013 & 46,40 & 44,01 & 9,59 \\
& 2014 & 63,16 & 22,32 & 14,53 \\
\hline \multirow{2}{*}{ Дерново-літогенні грунти } & 2012 & 55,46 & 39,65 & 4,89 \\
на лесоподібних суглинках & 2013 & 64,96 & 32,52 & 2,52 \\
& 2014 & 66,92 & 29,67 & 3,42 \\
\hline \multirow{2}{*}{ Педозем } & 2012 & 62,03 & 35,17 & 2,80 \\
& 2013 & 49,19 & 46,45 & 4,36 \\
\multirow{2}{*}{ Дерново-літогенні грунти } & 2014 & 83,36 & 13,42 & 3,22 \\
\multirow{2}{*}{ на сіро-зелених глинах } & 2012 & 89,03 & 7,23 & 3,74 \\
& 2013 & 82,03 & 12,64 & 5,33 \\
\hline
\end{tabular}

Примітки: SF - сапрофаги, $\mathrm{FF}$ - фітофаги, ZF - зоофаги.

Можна зазначити, що вигляд угруповання безхребетних дерново-літогенніх грунтів на сіро-зелених глинах із точки зору ценоморфічного аналізу воліс до степових біоценозів. У гігроморфічному аспекті угруповання можна охарактеризувати як мезоксерофільне, яке тяжіс до сухуватих біотопів. У трофоценоморфічній структурі домінують мегатрофоценоморфи. Отже, угруповання грунтової мезофауни віддає перевагу біотопам із багатими, родючими грунтами. У спектрі топоморф превалюють епігейні, які бігають по поверхні грунту, форми. Це свідчить про кращий розвиток органічних горизонтів порівняно 3 мінеральними горизонтами грунту. У структурі трофоморф значно переваже кількість фітофагів, що індикує переважання процесів мінералізації рослинних залишків над процесом гуміфікації. У спектрі фороморф домінує фороморфа $\mathrm{A}_{3}$ - тварини, які пересуваються без активного прокладання ходів і розміри тіла яких більші за порожнини у підстилці, що також свідчить про кращий розвиток органічних порівняно 3 мінеральними горизонтами грунту.

Вигляд угруповання безхребетних педоземів із погляду ценоморфічного аналізу воліс до степових біоценозів. У гігроморфічному аспекті у 2012 та 2014 рр. угруповання можна охарактеризувати як мезоксерофільне, яке тяжіє до сухуватих біотопів. У 2013 році угруповання ксеромезофільне та воліє до свіжуватих біотопів. У трофоценоморфічній структурі домінують мегатрофоценоморфи, тому угруповання грунтової мезофауни віддає перевагу біотопам із багатими, родючими грунтами. У спектрі топоморф превалюють епігейні, які бігають по поверхні грунту, форми, що свідчить про кращий розвиток органічних порівняно 3 мінеральними горизонтами грунту. У структурі трофоморф у 2012 та 2014 р. значно переважає кількість фітофагів, а, отже, і процес мінералізації рослинних залишків над процесом гуміфікації. У 2014 році домінуюче положення займали також сапрофаги та фітофаги. Це свідчить про те, що процеси мінералізації та гуміфікації відбувалися на одному рівні. У спектрі фороморф домінує фороморфа $\mathrm{A}_{3}-$ тварини, які пересуваються без активного прокладання ходів і розміри тіла яких більші за порожнини у підстилці, що також свідчить про кращий розвиток органогенних порівняно 3 мінеральними горизонтами технозему.

\section{Висновки}

В угрупованнях грунтової мезофауни техноземів установлено 123 види безхребетних тварин. Ці угруповання - степовий моноценоз зі схильністю до трансформації у псевдомоноценоз за рахунок збільшення ролі пратантів. Найадаптованіші до ксерофільних умов існування - угруповання грунтової мезофауни дерново-літогенних грунтів на сіро-зелених глинах і на лесоподібних суглинках. У педоземах і дерново-літогенних грунтах на червоно-бурих глинах угруповання мають більш мезофільний характер. Трофоценоморфічна структура угруповання грунтової мезофауни вказує на значний потенціал родючості штучно створених грунтів. Структура аероморф підкреслює значну здатність техноземів до утворення тріщин і пор та, відповідно, до гіпераерації. Домінантна складова угруповання грунтової мезофауни - гіперкарбонатофіли. На фоні загального степового характеру, угруповання грунтової мезофауни мають топоморфічну структуру, не характерну для природних степових біогеоценозів чорноземів на лесоподібних суглинках. У структурі трофоморф значно переважає кількість фітофагів, що індикує переважання процесів мінералізації рослинних залишків над процесом гуміфікації. У спектрі фороморф домінують тварини, які пересуваються без активного прокладання ходів.

\section{References}

Akimov, M. P. (1954). Biomorphological method of studying of biocoenosis. Bulletin of Naturalists Society, 59(3), 27-36.

Andrusevich, K. V., Zhukov, A. V., \& Kunah, O. N. (2014). Ecomorphic organisation of the mesopedobionts community as the basis of the anthropogenic soils zoological diagnostic. The Journal of V. N. Karazin Kharkiv National University, 22, 89-97.

Barois, I., Villemin, G., Lavelle, P., \& Toutain, F. (1993). Transformation of the soil structure through Pontoscolex corethrurus (Oligochaeta) intestinal tract. Geoderma, 56, 57-66.

Brygadyrenko, V. V. (2016). Effect of canopy density on litter invertebrate community structure in pine forests. Ekológia (Bratislava), 35(1), 90-102.

Brygadyrenko, V. V. (2016). Influence of litter thickness on the structure of litter macrofauna of deciduous forests of Ukraine's steppe zone. Visnyk of Dnipropetrovsk University. Biology, Ecology, 24(1), 240-248.

Decaëns, T., \& Rossi, J. P. (2001). Spatio-temporal structure of earthworm community and soil heterogeneity in a tropical pasture. Ecography, 24(6), 671-682.

Decaëns, T., Jiménez, J. J., Gioia, C., Measey, G. J., \& Lavelle, P. (2006). The values of soil animals for conservation biology. European Journal of Soil Biology, 42(1), S23-S38.

Didukh, Y. P. (2011). The ecological scales for the species of Ukrainian flora and their use in synphytoindication. Phytosociocentre, Kyiv.

Drake, J. A. (1990). Communities as assembled structures: Do rules govern pattern? Trends in Ecology and Evolution, 5, 159-164.

Faly, L. I., Kolombar, T. M., Prokopenko, E. V., Pakhomov, O. Y., \& Brygadyrenko, V. V. (2017). Structure of litter macrofauna communities in poplar plantations in an urban ecosystem in Ukraine. Biosystems Diversity, 25(1), 29-38.

Gilarov, M. S. (1965). Zoological methods of the soils diagnostic. Nauka, Moscow.

Gongalsky, K. B., Gorshkova, I. A., Karpov, A. I., \& Pokarzhevskii, A. D. (2008). Do boundaries of soil animal and plant communities coincide? A case study of a Mediterranean forest in Russia. European Journal of Soil Biology, 44(4), 355-363.

Gongalsky, K. B., Zaytsev, A. S., \& Savin, F. A. (2009). Spatial distribution of soil animals: A geostatistical approach. Biology Bulletin Reviews, 70(6), 484-494.

Jiménez, J. J., Decaëns, T., Lavelle, P., \& Rossi, J.-P. (2014). Dissecting the multiscale spatial relationship of earthworm assemblages with soil environmental variability. BMC Ecology, 14-26.

Jones, C. G., Lawton, J. H., \& Shachak, M. (1994). Organisms as ecosystem engineers. Oikos, 69, 373-386.

Jones, C. G., Lawton, J. H., \& Shachak, M. (1997). Positive and negative effects of organisms as physical ecosystem engineers. Ecology, 78(7), 1946-1957.

Kharytonov, M., Babenko, M., Velychko, O., \& Pardini, G. (2018). Prospects of medicinal herbs management in reclaimed minelands of Ukraine. Ukrainian Journal of Ecology, 8(1), 527-532.

Krivolutsky, D. A. (1994). Soil fauna in ecological control. Nauka, Moscow.

Kunah, O. N. (2016). Functional and spatial structure of the urbotechnozem mesopedobiont community. Visnyk of Dnipropetrovsk University. Biology, Ecology, 24(2), 473-483.

Kunah, O. N., Prokopenko, E. V., \& Zhukov, A. V. (2014). Ecomorphic organisation of the Ukraine steppe zone spider community. Gruntoznavstvo, 15, 101-119.

Lavelle, P., Bignell, D., Lepage, M., Wolters, V., Roger, P., Ineson, P., Heal, O. W., \& Dhillion, S. (1997). Soil function in a changing world: The role of invertebrate ecosystem engineers. European Journal of Soil Biology, 33, 159-193.

Mordkovich, V. G. (1977). Zoological diagnostics of the soil in forest-steppe and steppe zones of the Sibiria. Nauka, Novosibirsk.

Mordkovich, V. G. (2013). Zoological diagnostic of the soils: Imperatives, function and place in the soil science and pedology. Journal of General Biology, 74(6), 463-471.

Rossi, J. P. (2003). Clusters in earthworm spatial distribution. Pedobiologia, 47, 490-496.

Svyrydchenko, A. O., \& Brygadyrenko, V. V. (2014). Trophic preferences of Rossiulus kessleri (Diplopoda, Julidae) for the litter of various tree species. Folia Oecologica, 41(2), 202-212.

Whalen, J. K. (2004). Spatial and temporal distribution of earthworm patches in corn field, hayfield and forest systems of southwestern Quebec, Canada. Applied Soil Ecology, 27(2), 143-151.

Williams, V. R. (1947). Pedology. Selhozgiz, Moscow. 
Zhukov O. V., Zadorozhna, G. O., Maslikova, K. P., Andrusevych, K. V., \& Lyadskaya, I. V. (2017). Tehnosoils ecology. Zhurfond, Dnipro.

Zhukov, A. V. (2015). Phytoindicator estimation of the multidimensional scaling of the plant community structure. Biological Bulletin of Bogdan Chmelnitskiy Melitopol State Pedagogical University, 1(1), 69-93.

Zhukov, A. V., \& Shatalin, D. B. (2016). Hygrotope and trophotope of the steppe pridniprovie biogeoceonosis as determinants of the earthworms (Lumbricidae) communities $\beta$-diversity. Biological Bulletin of Bogdan Chmelnitskiy Melitopol State Pedagogical University, 6 (2), 129-157.

Zhukov, A. V., \& Zadorozhnaya, G. A. (2016). Spatio-temporal dynamics of the penetration resistance of recultivated soils formed after open cast mining. Visnyk of Dnipropetrovsk University. Biology, Ecology, 24(2), 324-331.

Zhukov, A. V., Kunah, O. N., Novikova, V. A., \& Ganzha, D. S. (2016). Phytoindication estimation of soil mesopedobionts communities catena and their ecomorphic organization. Biological Bulletin of Bogdan Chmelnitskiy Melitopol State Pedagogical University, 6(3), 91-117.

Zhukov, O. V. (2009). Ecomorphological analysis of soil animal consortia. Svidler, Dnepropetrovsk.

Zhukov, O. V., Kunah, O. M., \& Dubinina, Y. Y. (2017). Sensitivity and resistance of communities: Evaluation on the example of the influence of edaphic, vegetation and spatial factors on soil macrofauna. Biosystems Diversity, 25(4), 328-341.

Zhukov, O. V., Kunah, O. N., \& Novikova, V. A. (2016). The functional organisation of the mesopedobionts community of sod pinewood soils on arena of the river Dnepr. Visnyk of Dnipropetrovsk University. Biology, Ecology, 24(1), 26-39.

Zverkovskyi, V. M., Sytnyk, S. A., Lovynska, V. M., Kharytonov, M. M., \& Mykolenko, S. Y. (2017). Remediation potential of forest-forming species in the reclamation planting. Ukrainian Journal of Ecology, 7(3), 64-72. 